\title{
Effect of Thermal Modification on the Surface Quality of a Coating Applied to Wood via the Electrostatic Spray Deposition Technique
}

\author{
Nadir Ayrilmis, ${ }^{\mathrm{a}, *}$ Memiş Akkuş, ${ }^{\mathrm{b}}$ and Sena Nur Y1lmaz ${ }^{\mathrm{c}}$ \\ The surface properties of thermally modified ash wood with a powder \\ coating were investigated, and the results were compared to the \\ unmodified wood. The wood specimens were sanded with 80 grit \\ sandpaper and then pre-heated at $80^{\circ} \mathrm{C}$ for $5 \mathrm{~min}$ in an infrared oven. The \\ surface of the unmodified and the modified wood specimens were coated \\ with an epoxy/polyester (1 to 1 ratio) hybrid coating using an electrostatic \\ corona spray gun at the pilot plant established in the laboratory. The \\ coatings on the wood specimens were cured at different curing conditions \\ in an infrared oven, i.e., $120^{\circ} \mathrm{C} / 15 \mathrm{~min}, 140^{\circ} \mathrm{C} / 10 \mathrm{~min}$, and $160^{\circ} \mathrm{C} / 10 \mathrm{~min}$. \\ The results showed that the thermal modification (TM) of the wood caused \\ a slight decrease in the mechanical performance of the surface system \\ (wood substrate and coating film). For example, the scratch and abrasion \\ resistance of the unmodified specimens at the curing temperature of 120 \\ ${ }^{\circ} \mathrm{C}$ were $3.33 \mathrm{~N}$ and 135 revolutions but were $3.12 \mathrm{~N}$ and 120 revolutions \\ after the TM. However, the average surface roughness $(1.26 \mathrm{mu})$ and \\ contact angle $\left(60.8^{\circ}\right)$ of the distilled water on the cured coatings on the \\ modified wood were lower than those on the unmodified wood $(1.86 \mathrm{mu}$ \\ and $80.8^{\circ}$, respectively).
}

Keywords: Electrostatic powder coating; Thermally modified wood; Surface quality; Ash wood

Contact information: a: Department of Wood Mechanics and Technology, Faculty of Forestry, Istanbul University-Cerrahpasa; Bahcekoy, Sariyer, Istanbul 34473 Turkey; b: Department of Woodworking Industrial Engineering, Faculty of Forestry, Düzce University, Düzce 81620 Turkey; c: Soganl Neighborhood, Yllmaz Street, Building No. 9, Apartment No. 14 Bahcelievler District, Istanbul 34183 Turkey; *Corresponding author: nadiray@istanbul.edu.tr

\section{INTRODUCTION}

The thermal modification (TM) of wood for outdoor applications has a long history in the wood industry, due to its unique properties of thermally modified wood, e.g., improved dimensional stability and biological durability, compared to unmodified wood. Although there are some effective wood modification techniques, e.g., acetylation and furfurylation, these processes use chemicals, which are harmful to the environment after the disposal of wood. Among the wood modification techniques, the most accepted one is the TM, which is an environmentally friendly technique that does not use any toxic chemicals. Despite the positive features of the TM, it affects the surface properties of the wood, which generally results in surface inactivation, reduced surface roughness, enhanced hydrophobic behavior, i.e., a decrease in the amount of free hydroxyl groups, and a darkened surface (Hill et al. 2021). Some chemical reactions occur in the wood during the thermal treatment, e.g., hydrolysis and oxidation, which cause the reduction of free hydroxyl groups and surface inactivation (Hakkou et al. 2005; Petric et al. 2009; Miklečić and Jirouš-Rajković 2016). Previous studies reported that the surface inactivation caused 
by the TM influences the wettability, which plays a role in the bonding mechanism between wood and certain coatings (Jarusombuti et al. 2010; Hubbe et al. 2015; Zhang and Yu 2015). Coating systems need to spread and penetrate the surface of the wood for good bonding to occur.

Although electrostatic powder coating technology has been used in the metal industry in the USA and Europe since the early 1960s, it is still relatively new for the wood industry. In the early 2000, electrostatic powder coating for non-conductive substrates, especially medium density fibreboard (MDF) panels, was introduced to the furniture industry in order to benefit from the advantages of this technology. The use of powder coatings in the panel-type furniture industry has considerably increased over the last decade, due to its five considerable advantages, i.e., its efficiency in powder use, excellent finish, economic benefits, energy savings, and being an environmentally friendly material. Today, two-thirds of the coatings used in the wood and wood-based panels industries are still based on solvent-based paints, because of their considerable advantages, e.g., low cost, easy supply, highly durable finish, and high gloss finish, when compared to the waterbased paints and powder coatings. Solvent-based paints are potentially hazardous to human and environment health because they contain some harmful volatile organic compounds (VOCs) such as formaldehyde, toluene, ethylbenzene, and xylene. An increasing awareness of environmental issues has increased the use of environmentally friendly and cost-effective coating systems. At this point, powder coatings present a good opportunity for the furniture industry. The most used thermosetting powders are epoxy, polyester, epoxy/polyester hybrids, polyurethane, acrylic, and hybrid compositions. The powder coatings are applied to the wood material surface using electrostatic forces. Then, the thermosetting powder coating melts and flows out on the surface of the substrate when the heat is increased in a curing oven. After a while, the coating is cured to the surface, which results in a network structure of cross-linked polymers with a higher molecular weight (Akkuş et al. 2021). The utilization of thermally modified wood for indoor or outdoor applications has progressively increased due to its above-mentioned advantages. Previous studies have reported that the surface of the wood after the TM shows some changes when compared to unmodified wood (Hakkou et al. 2005; Zhang et al. 2015; Miklečić and Jirouš-Rajković 2016; Hill et al. 2021). These changes include a decreased wettability and an inactivation of the surface. The presence of hydroxyl groups on the wood surface are affected by the thermal treatment. The hydroxyl groups react with the functional groups of the adhesives such as urea-formaldehyde, melamine formaldehyde. When the wood is exposed to elevated temperatures, the number of the hydroxyl groups decreases, which negatively affect the bonding performance between the wood and resin. These properties should be also considered before the overlay coating. The curing mechanism of epoxy/polyester thermosets involves reaction of the acid functionality with epoxy followed by esterification of the epoxy hydroxyl groups with the acids. Compounds such as amines and phosphonium salts catalyze these reactions (Petriccione 2011).

Wood-based panel producers, furniture producers, and other users are still new to this technology, and they need to be informed about the details of this process and given key precautions to ensure a successful finishing with powder coatings. The curing step is critical for the powder coatings. When the powder coating is applied on the surface of MDF surface at low temperatures, it is essential to understand the curing behavior of the powder coating. Specifically, the curing behavior of the powder coatings is primarily affected by the curing conditions, e.g., air flow, the temperature, and duration. The present study was aimed at understanding the effect of the thermal treatment of wood on the curing behavior

Ayrilmis et al. (2021). "Coating thermally treated wood," BioResources 16(4), 7355-7366. 7356 
and surface quality of the powder coatings at elevated temperatures in the curing oven. Although the coating properties of thermally modified wood coated with solvent or waterbased paints have been investigated in previous studies by Miklečić et al. (2011), JiroušRajković and Miklečić (2019), Nejad et al. (2019), and Slabejová et al. (2019), these studies did not explore the influence of the TM on various properties of coatings applied via the electrostatic spray deposition technique.

\section{EXPERIMENTAL}

\section{Wood Specimens}

Thermally modified ash wood specimens (Fraxinus excelsa Thunb.) with $320 \mathrm{~mm}$ x $135 \mathrm{~mm}$ x $20 \mathrm{~mm}$ dimensions were obtained from the Novawood Company (Duzce city, Turkey) (Fig. 1a). The wood specimens were thermally modified at the Novawood factory (Duzce city, Turkey) based on the Thermowood ${ }^{\circledR}$ process under Finnish patent (Fig. 1b). The average moisture content of the thermally treated wood specimens was $7 \%$ while the average moisture content of the unmodified wood specimens was $12 \%$. The thickness of the specimens was reduced to $10 \mathrm{~mm}$ using a thickness planer machine so that the specimens were easy to place in the abrasion and scratch test equipment.

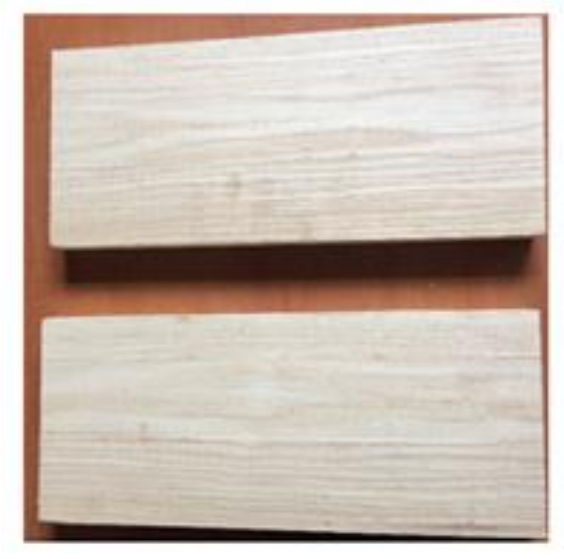

(a)

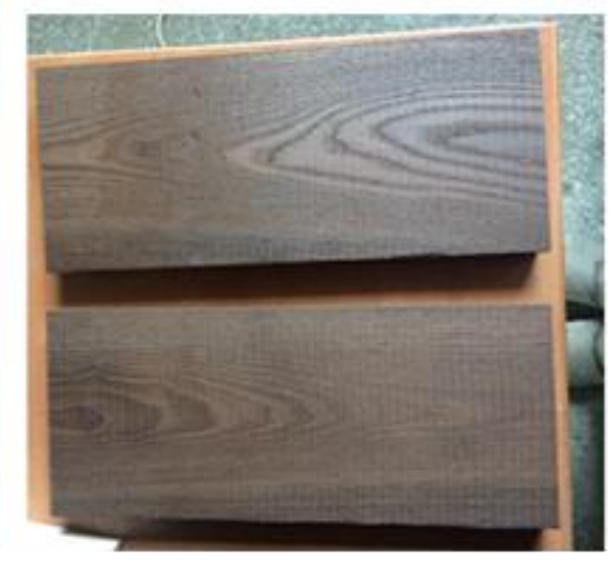

(b)

Fig. 1. The (a) unmodified ash wood specimens; and (b) thermally modified ash wood specimens

\section{Powder Coatings}

An epoxy/polyester hybrid (at a 1:1 ratio) powder coating was used in the experiments (Table 1). It was supplied by a commercial producer of electrostatic powder coatings (Mikroton Chemical Company, Istanbul, Turkey). The code of the coatings was RAL 9016, which is used for interior applications.

\section{Application of Powder Coatings to the Surface of Wood}

The top and bottom sides of the unmodified and modified wood specimens were sanded with 80 grit sandpaper to achieve a smooth surface before the powder coating application. The wood specimens were placed into the infrared oven at $80{ }^{\circ} \mathrm{C}$ for $5 \mathrm{~min}$. One of the primary challenges of wood and wood-based panels in terms of coating applications is that the electrostatic coating application needs an electrically conductive substrate. 
Table 1. Physical, Mechanical, and Chemical Properties of the Epoxy/Polyester (1:1) Hybrid Powder Coating (Code: RAL 9016)

\begin{tabular}{|c|c|c|c|}
\hline Test type & Unit & \multirow{2}{*}{ Standard Number } & \multirow{2}{*}{ Value } \\
\hline \multicolumn{2}{|c|}{ Physical tests } & & \\
\hline Gloss & $\left(60^{\circ}\right)$ & EN ISO 2813 (2014) & 5 to 95 \\
\hline Impact resistance & $\mathrm{kg} \cdot \mathrm{cm}$ & ISO 6272 (2011) & 80 to 100 \\
\hline Flexibility & $\mathrm{mm}$ & EN ISO 1520 (2006) & 7 to 8 \\
\hline Buchholz indentation test & - & EN ISO 2815 (2003) & 90 to 100 \\
\hline Cross-cut & Gt & EN ISO 2409 (2020) & 0 \\
\hline Density & $\mathrm{g} / \mathrm{cm}^{3}$ & ISO 8130-3 (1992) & 1.30 to 1.70 \\
\hline Flow property & - & ISO 8130-5 (1992) & 120 to 175 \\
\hline \multicolumn{2}{|c|}{ Chemical tests } & & \\
\hline Corrosion test (salt test) & Hour & ISO 7253 (1996) & $1000+$ \\
\hline
\end{tabular}

Following the pre-treatment, the wood specimens were immediately transported to the hangers of the powder coating application system (Fig. 2). The pneumatic control section of the corona type gun is shown in Fig. 3. Single layer powder coating (epoxy/polyester hybrid at a 1:1 ratio) was uniformly applied to the surface of the wood specimens via the corona spray gun for 2 min (Fig. 4). The electrostatic powder coating was applied using a pilot scale coating system manufactured by Boysan Electrostatic and Wet Coating Application Systems (Istanbul city, Turkey). The specimens were placed into the infrared oven in order to cure the powder coatings. To understand the effects of the curing conditions, i.e., the temperature and duration, three different curing temperatures were used during the experiments. The curing conditions of the specimens are shown in Table 2. The coated specimens were conditioned to a constant weight at a temperature of $20{ }^{\circ} \mathrm{C}$ and a relative humidity of air $65 \%$. The dry powders were made electrostatic by charging the powder particles at the tip of the corona spray gun. The electrical current and voltage applied by the corona spray gun were $80 \mu \mathrm{A}$ and $50 \mathrm{kV}$, respectively. A total of 18 specimens, 3 for each treatment, were used in the experiments (Table 2). The mean density of the unmodified and modified specimens ranged from 0.52 to $0.57 \mathrm{~g} / \mathrm{cm}^{3}$.

\section{Determination of the Coating Thickness}

The coating thickness of the wood specimens was measured with a PosiTector 200 Coating Thickness Gage (DeFelsko Inspection Instruments, Ogdensburg, NY), which measured the coating thickness between 20 and $300 \mu \mathrm{m}$ (Fig. 4).

\section{Determination of the Scratch and Abrasion Resistance}

The abrasion and scratch resistance tests were carried out according to the EN 4382 EN 438-2:2016+A1 (2018) standard (Fig. 4). Both tests were carried out on the fully cured coatings on the unmodified and modified wood specimens. To carry out the scratch and abrasion resistance tests, a $6 \mathrm{~mm}$ diameter screw hole was opened on the diagonal center of the specimens, which had dimensions of $100 \mathrm{~mm}$ x $100 \mathrm{~mm} \times 10 \mathrm{~mm}$. Then, the specimen was fixed to the rotating table. The scratch resistance of the coatings was determined with a universal motorized scratch tester (Taber 551 Shear/Scratch tester, Taber Industries, North Tonawanda, NY). Three specimens were used for each treatment given in Table 2. 


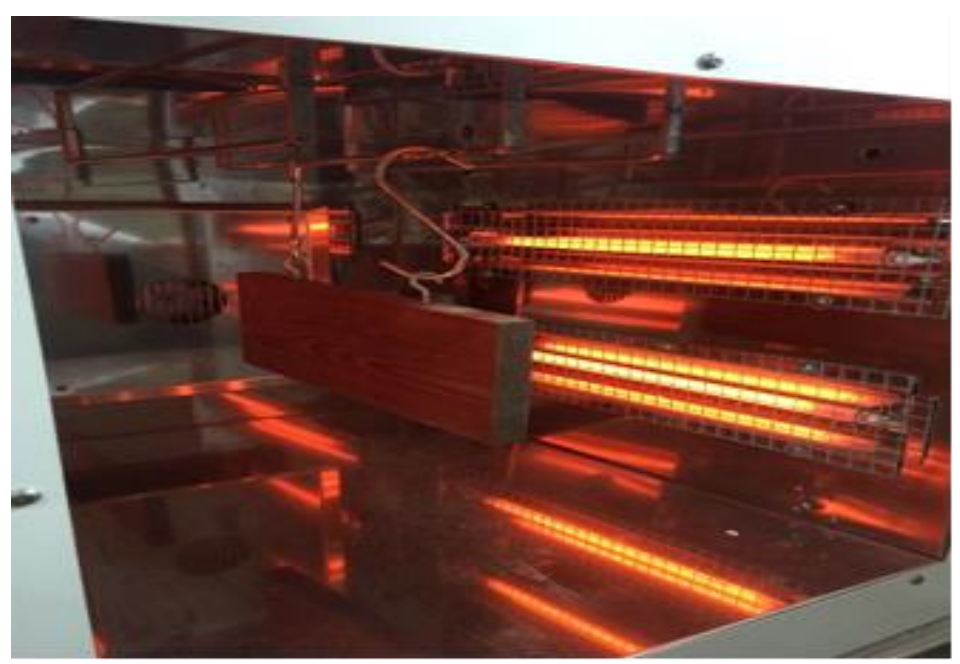

Fig. 2. Pre-heating of the wood specimen in the infrared oven

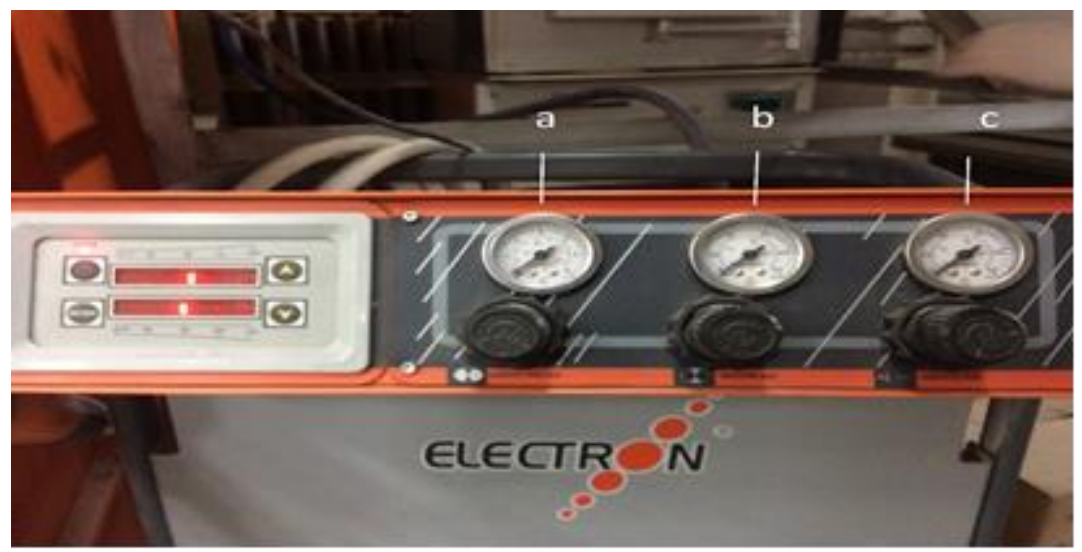

Fig. 3. Pneumatic control section of the corona type electrostatic powder coating gun

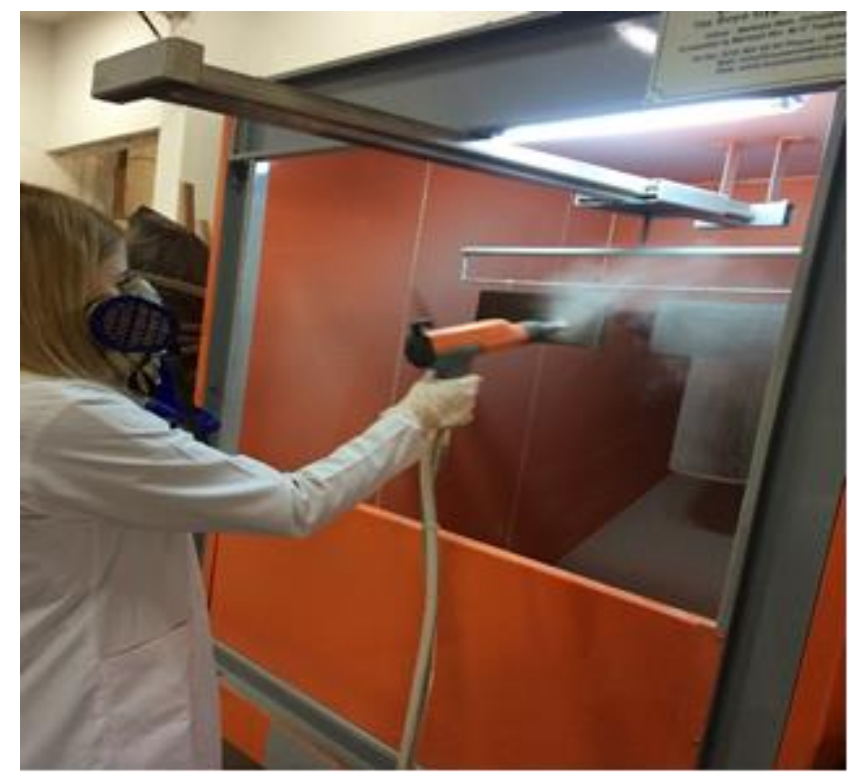

Fig. 4. Application of the powder coatings on the wood specimens using the corona spray gun 
The test specimens were firmly fixed through their central holes on the rotating table of a Taber® rotary abraser (Taber 5131 Abraser, Taber Industries, North Tonawanda, $\mathrm{NY}$ ). The top surface of the coated specimens was exposed to two rotating abrasive discs coated with S-42 sandpaper and additional weights (500 g for each disc). The specimens were then subjected to rotation. The total number of cycles required to wear out threefourths of the coated specimens was recorded as the abrasion resistance. Three specimens were used for each treatment given in Table 2.

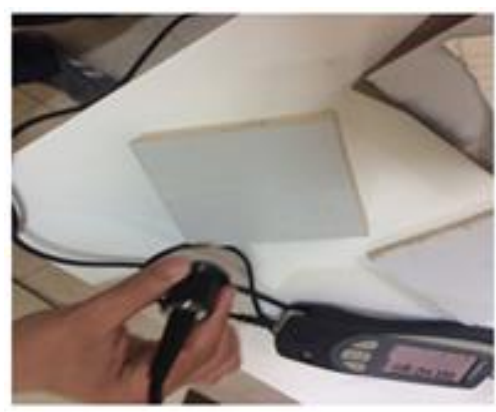

(a)

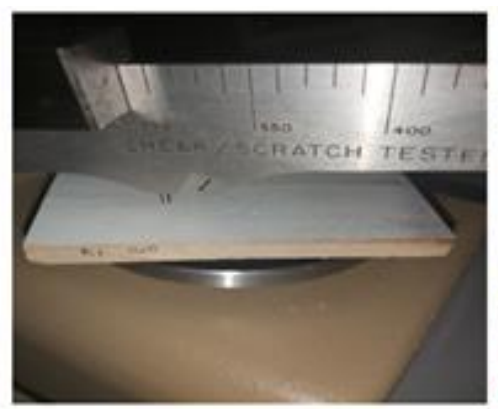

(b)

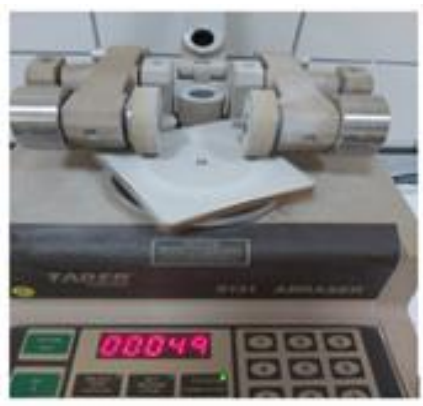

(c)

Fig. 4. The (a) measurement of the coating thickness; (b) shear/scratch resistance test; and (c) abrasion resistance test

\section{Determination of Surface Roughness and Wettability}

The roughness of the $100 \mathrm{~mm} \times 100 \mathrm{~mm} \times 10 \mathrm{~mm}$ coated specimens was determined via a stylus roughness tester (Mitutoyo Surftest ${ }^{\circledR}$ SJ-301, Mitutoyo Europe GmbH, Neuss, Germany). The surface roughness measurement was carried out according to EN ISO standard 4287:1997/AMD 1 (2009). The average roughness $\left(R_{\mathrm{a}}\right)$, maximum height of the measured profile $\left(R_{\mathrm{z}}\right)$, and the root mean square deviation of the measured profile $\left(R_{\mathrm{q}}\right)$ were taken. Ten surface roughness measurements were recorded for each type of wood. Five $100 \mathrm{~mm} \times 100 \mathrm{~mm}$ specimens were used for each wood treatment type. In addition, 10 total measurements for each treatment were taken ( 2 measurements for each specimen). The measurement points on the specimens were selected to represent all the surface of the wood specimen. The tracing speed of the stylus pin was $5 \mathrm{~mm} / \mathrm{s}$ and the total tracing length was $12.5 \mathrm{~mm}$.

The wettability behavior of the coated specimens was determined using a contact angle instrument with image analysis software (KSV-101, KSV Instruments Ltd., Helsinki, Finland). The digital images of a $5 \mu \mathrm{L}$ distilled water droplet were recorded with a video camera at $1 \mathrm{~s}$ intervals up to $5 \mathrm{~s}$. The contact angles recorded at $5 \mathrm{~s}$ was reported. A total of 10 measurements were recorded for each type of treatment given in Table 2, two measurements for each specimen.

\section{RESULTS AND DISCUSSION}

The abrasion and scratch resistance of the specimens are shown in Table 2. The unmodified specimens showed slightly higher abrasion and scratch resistance at all the curing temperatures. For example, the scratch and abrasion resistance of the coatings on the non-modified specimens at a curing temperature of $120{ }^{\circ} \mathrm{C}$ were found to be $3.33 \mathrm{~N}$ and 135 revolutions, respectively, while they were found to be $3.12 \mathrm{~N}$ and 120 revolutions 
for the modified wood specimens. Similar results were seen at curing temperatures of 140 ${ }^{\circ} \mathrm{C}$ and $160{ }^{\circ} \mathrm{C}$. The dry film thickness of the coatings on the unmodified wood were higher than the dry film thickness of the coatings on the thermally modified wood at all curing temperatures. A higher coating thickness on the unmodified wood may be one of the reasons why its mechanical performance was better than the mechanical performance of the surface system (wood substrate and coating film) on the thermally modified wood. The results of the coating thickness measurements showed that the amount the coating penetrated thermally modified wood was greater than the amount the coating penetrated the unmodified wood. This can be explained by lower surface roughness of the thermally modified wood (Jirouš-Rajković and Josip Miklečić 2019). Ayrilmis and Winandy (2009) reported that the TM of the wood reduced the wettability and adhesive bond strength of wood. When wood is exposed to thermal treatment at a temperature of approximately 200 ${ }^{\circ} \mathrm{C}$, its surface may experience inactivation, which results in a decrease in its wetting capability. The wettability affects the penetration of adhesives and coatings into the surface of wood, which is needed for the good mechanical interlocking. Particularly, hemicelluloses are degraded at high temperature thermal treatments, i.e., approximately $200{ }^{\circ} \mathrm{C}$, which explains the lower mechanical interlocking of the coatings on the modified wood when the coatings are cured (Hakkou et al. 2005; Hill et al. 2021).

The presence of hydroxyl groups on the wood surface significantly affects the bond with the $\mathrm{OH}$ groups of the epoxy. The decrease in the amount of the hydroxyl groups of the modified wood reduces the hydroxyl functionality of the epoxy resin. This negatively affects the crosslink possibility through the reaction between hydroxyl functionality and an epoxy ring (Petriccione 2011). It was thought to be a major reason for lower abrasion resistance and scratch resistance of the coatings on the modified wood.

Table 2. Film Thickness, Abrasion, and Scratch Resistance of the Coatings on the Unmodified and Modified Wood Specimens

\begin{tabular}{|c|c|c|c|c|c|}
\hline \multirow{2}{*}{$\begin{array}{l}\text { Specimen } \\
\text { Type }\end{array}$} & \multicolumn{2}{|c|}{ Infrared Oven Conditions } & \multirow{2}{*}{$\begin{array}{c}\text { Dry Coating } \\
\text { Thickness } \\
\text { (mu) }\end{array}$} & \multirow{2}{*}{$\begin{array}{c}\text { Abrasion } \\
\text { Resistance } \\
\text { of Coating } \\
\text { (Rev.) }\end{array}$} & \multirow{2}{*}{$\begin{array}{l}\text { Scratch } \\
\text { Resistance } \\
\text { of Coating } \\
\text { (N) }\end{array}$} \\
\hline & $\begin{array}{l}\text { Curing temperature } \\
\qquad\left({ }^{\circ} \mathrm{C}\right)\end{array}$ & $\begin{array}{l}\text { Curing time } \\
\text { (min) }\end{array}$ & & & \\
\hline \multirow{3}{*}{$\begin{array}{l}\text { Coating on } \\
\text { the } \\
\text { unmodified } \\
\text { wood }\end{array}$} & 120 & 15 & $71.4(10.8)$ & $135(26)$ & $3.33(0.28)$ \\
\hline & 140 & 10 & $72.6(15.7)$ & $187(0)$ & $3.45(0.35)$ \\
\hline & 160 & 10 & $85.0(17.3)$ & 195 (77) & $3.53(0.40)$ \\
\hline \multirow{3}{*}{$\begin{array}{l}\text { Coating on } \\
\text { the } \\
\text { modified } \\
\text { wood }\end{array}$} & 120 & 15 & $56.4(8.0)$ & $120(26)$ & $3.12(0.20)$ \\
\hline & 140 & 10 & $67.0(16.4)$ & $173(65)$ & $3.14(0.24)$ \\
\hline & 160 & 10 & $61.4(5.8)$ & $188(19)$ & $3.25(0.26)$ \\
\hline
\end{tabular}

The thickness of the coating film on the unmodified and modified wood surfaces are given in Table 2. It was clearly shown that the TM of the wood caused a lower film thickness at all curing temperatures. This may be explained by the lower surface roughness of the thermally modified wood, as shown in Table 3. Furthermore, the equilibrium moisture content of the thermally modified wood in a standard atmosphere considerably decreases (Prieto and Kiene 2018). The lower moisture content (7\%) of the modified wood may be another reason for the lower abrasion and scratch resistance of the coating, because the dielectric constant of wood decreases with decreasing moisture content, particularly in 
the face layers. The decrease in the dielectric constant negatively affects the powder deposition onto the wood substrate, which results in the poor adhesion of the powder coating to the substrate. The sorption and diffusion properties of heat-modified wood decrease after heat exposure (Kymäläinen et al. 2018). The moisture content and temperature of wood are two important factors affecting its electrical conductivity, which affect the retention of the powder on the wood surface, and the resulting coating film thickness (Schmidt et al. 2013).

When the curing temperature was increased from 120 to $160{ }^{\circ} \mathrm{C}$, the mechanical performance of the coating on the unmodified and modified wood specimens improved. The increase in the curing temperature decreased the improved surface smoothness and wettability of the wood specimens. This result revealed that the increased curing temperature provided the coating film better resistance to the abrasions and scratches. In addition, these results were consistent with previous studies (Lee et al. 1999; Andrei et al. 2000; Barletta et al. 2007). In a previous study, Akkuş et al. (2019) reported that the scratch resistance of particleboard and MDF coated with an epoxy/polyester hybrid powder coating were 2.80 and $2.50 \mathrm{~N}$, respectively. Barletta et al. (2007) reported that increasing the curing temperature did not have a major effect on the visual appearance of the specimen, but the adhesion of the coating and the abrasion resistance were strongly related to the curing conditions in the IR oven. This was because a fully cured thermosetting coating showed its full potential regarding its abrasion and scratch resistance, which allowed greater resistance to the action of the scratch indenter.

The contact angle values of the water measured at $5 \mathrm{~s}$ are given in Table 3 . The wettability of the cured coatings on the thermally modified wood specimens was found to be higher than the wettability of the coatings on the unmodified wood specimens. The difference in the coating wettability of the modified and unmodified specimens decreased as the curing temperature was increased from 120 to $160{ }^{\circ} \mathrm{C}(25 \%$ to $4 \%)$. The highest contact angle (with a value of $80.8^{\circ}$ ) was found from the coating on the unmodified specimen. The contact angle values of all the coatings on the modified and unmodified wood specimens were lower than $90^{\circ}$, which denoted that the coating surface was hydrophilic. The increase in the curing temperature decreased the surface roughness and improved the wettability of the coatings. This may be explained by the cross-linking mechanism of the coating, which corresponds to an increased curing temperature.

The coatings on the modified wood specimens showed a lower surface roughness than the coatings on the unmodified wood at all curing temperatures. For example, the average roughness of the coatings on the modified wood at a curing temperature of $120{ }^{\circ} \mathrm{C}$ was $1.28 \mu \mathrm{m}$ while it was found to be $1.95 \mu \mathrm{m}$ for the unmodified wood coatings. The surface roughness of the coatings improved as the curing temperature increased. The decrease in the surface roughness of the coatings cured at elevated temperatures was primarily attributed to the viscosity drop of the coatings due to the increased temperature during the curing of the coatings. Ayrilmis (2020) investigated the surface roughness of epoxy/polyester hybrid powder coatings on oriented strandboard (OSB). A decrease in the surface roughness of the coatings occurred when the curing temperature was increased from 120 to $160{ }^{\circ} \mathrm{C}$ in the infrared oven.

Ayrilmis et al. (2021). "Coating thermally treated wood," BioResources 16(4), 7355-7366. 7362 
Table 3. Surface Roughness and Wettability of the Coatings on the Unmodified and Modified Wood Specimens

\begin{tabular}{|c|c|c|c|c|c|c|}
\hline \multirow{2}{*}{$\begin{array}{l}\text { Specimen } \\
\text { Type }\end{array}$} & \multicolumn{2}{|c|}{ Infrared Oven Conditions } & \multicolumn{3}{|c|}{ Surface Roughness Parameters (mu) } & \multirow{2}{*}{$\begin{array}{c}\text { Contact } \\
\text { Angle of } \\
\text { Distilled } \\
\text { Water }\left(^{\circ}\right) \\
\begin{array}{c}\text { Duration } \\
(5 \mathrm{~s})\end{array}\end{array}$} \\
\hline & $\begin{array}{c}\text { Curing } \\
\text { temperature } \\
\left({ }^{\circ} \mathrm{C}\right)\end{array}$ & $\begin{array}{c}\text { Curing } \\
\text { time (min) }\end{array}$ & $R_{\mathrm{a}}$ & $R_{y}$ & $R_{\mathrm{z}}$ & \\
\hline \multirow{3}{*}{$\begin{array}{l}\text { Coating on } \\
\text { the } \\
\text { unmodified } \\
\text { wood }\end{array}$} & 120 & 15 & $1.95(0.4)$ & 11.69 (2.7) & $8.38(2.8)$ & $80.8(6.3)$ \\
\hline & 140 & 10 & $2.64(0.7)$ & $14.88(4.5)$ & $10.25(3.5)$ & $75.9(6.3)$ \\
\hline & 160 & 10 & $1.85(1.2)$ & $7.96(5.3)$ & $6.25(4.1)$ & $60.5(14.4)$ \\
\hline \multirow{3}{*}{$\begin{array}{l}\text { Coating on } \\
\text { the } \\
\text { modified } \\
\text { wood }\end{array}$} & 120 & 15 & $1.28(0.5)$ & $8.07(4.1)$ & $5.42(3.0)$ & $69.1(10.8)$ \\
\hline & 140 & 10 & $1.86(0.8)$ & $12.4(4.6)$ & $8.33(4.0)$ & $63.3(5.4)$ \\
\hline & 160 & 10 & $1.60(0.8)$ & $6.53(5.9)$ & $4.64(4.6)$ & $58.0(11.1)$ \\
\hline
\end{tabular}

\section{CONCLUSIONS}

1. The scratch and abrasion resistance of the coatings on the thermally modified ash wood were slightly lower than the scratch and abrasion resistance of the coating on the unmodified wood. The dry film thickness of the coatings on the unmodified wood was higher than the dry film thickness of the coatings on the modified wood at all curing temperatures. This may be one of the reasons for the lower mechanical performance of the coatings on the modified wood.

2. The thermal modification (TM) reduced the number of the hydroxyl groups of the modified wood, which adversely affects the crosslink possibility between the hydroxyl groups of the modified wood and epoxy ring (Petriccione 2011). It was thought to be a major reason for the lower abrasion resistance and scratch resistance of the coatings on the modified wood.

3. The coatings on the modified wood specimens had a lower surface roughness and water contact angle values than the coatings on the unmodified wood specimens at all curing temperature.

4. Increasing the curing temperature improved the abrasion resistance and scratch resistance of the powder coatings on both the unmodified and modified wood specimens.

5. The curing temperature of the powder coating can provide useful indication to powder coaters to obtain better surface quality.

\section{ACKNOWLEDGMENTS}

The authors thank Novawood Company (Duzce city, Turkey) for supplying the thermally treated ash wood used in this investigation. 


\section{REFERENCES CITED}

Akkus, M., Akbulut, T., and Candan, Z. (2019). “Application of electrostatic powder coating on wood composite panels using a cooling method. Part 1: Investigation of water intake, abrasion, scratch resistance, and adhesion strength," BioResources 14(4), 9557-9574. DOI: 10.15376/biores.14.4.9557-9574.

Akkuş, M., Akbulut, T., and Candan, Z. (2021). "Formaldehyde emission, combustion behavior, and artificial weathering characteristics of electrostatic powder coated wood composite panels," Wood Material Science \& Engineering (in press).

DOI: 10.1080/17480272.2021.1901142

Andrei, D. C., Hay, J. N., Keddie, J. L., Sear, R. P., and Yeates, S.G. (2000). "Surface levelling of thermosetting powder coatings: Theory and experiment," Journal of Physics D: Applied Physics 33, 1975-1981. DOI: 10.1088/0022-3727/33/16/307.

Ayrilmis, N. (2020). "Surface properties of oriented strand board coated by electrostatic dry powder spray deposition technique," BioResources 15(1), 1521-1530. DOI: 10.15376/biores.15.1.1521-1530.

Ayrilmis, N. and Winandy, J. E. (2009). "Effects of post heat-treatment on surface characteristics and adhesive bonding performance of medium density fiberboard," Materials and Manufacturing Processes 24(5), 594-599. DOI: 10.1080/10426910902748032.

Barletta, M., Lusvarghi, L., Mantini F. P., and Rubino, G. (2007). "Epoxy-based thermosetting powder coatings: Surface appearance, scratch adhesion and wear resistance," Surface and Coating Technology 201(16-17), 7479-7504. DOI: 10.1016/j.surfcoat.2007.02.017.

EN 438-2:2016+A1 (2018). "High-pressure decorative laminates (HPL) - Sheets based on thermosetting resins (usually called laminates) - Part 2: Determination of properties," European Committee for Standardization, Brussels, Belgium.

Hakkou, M., Pétrissans, M., Bakali, I. E., Gérardin, P., and Zoulalian, A. (2005). "Wettability changes and mass loss during heat treatment of wood," Holzforschung 59, 35-37. DOI: 10.1515/hf.2005.006.

Hill, C., Altgen, M., and Rautkari, L. (2021). "Thermal modification of wood - A review: Chemical changes and hygroscopicity," Journal of Material Science 56, 6581-6614. DOI: $10.1007 / \mathrm{s} 10853-020-05722-\mathrm{z}$.

Hubbe, M. A., Gardner, D. J., and Shen, W. (2015). "Contact angles and wettability of cellulosic surfaces: A review of proposed mechanisms and test strategies," BioResources 10(4), 8657-8749. DOI: 10.15376/biores.10.4.Hubbe_Gardner_Shen.

ISO 1520 (2006). "Paints and varnishes - Cupping test," International Organization for Standardization, Geneva, Switzerland.

ISO 2409 (2020). "Paints and varnishes - Cross-cut test," International Organization for Standardization, Geneva, Switzerland.

ISO 2808 (2019). "Paints and varnishes - Determination of film thickness," International Organization for Standardization, Geneva, Switzerland.

ISO 2813 (2014). "Paints and varnishes - Determination of gloss value at $20^{\circ}, 60^{\circ}$ and $85^{\circ}$," International Organization for Standardization, Geneva, Switzerland.

ISO 2815 (2003). "Paints and varnishes - Buchholz indentation test," International Organization for Standardization, Geneva, Switzerland.

ISO 4287:1997/AMD 1 (2009). “Geometrical product specifications (GPS) - Surface texture: Profile method - Terms, definitions and surface texture parameters - 
Amendment 1: Peak count number," International Organization for Standardization, Geneva, Switzerland.

ISO 6272 (2011). "Paints and varnishes - Rapid-deformation (impact resistance) tests Part 1: Falling-weight test, large-area indenter," International Organization for Standardization, Geneva, Switzerland.

ISO 7253 (1996). "Paints and varnishes - Determination of resistance to neutral salt spray (fog)," International Organization for Standardization, Geneva, Switzerland.

ISO 8130-3 (1992). "Coating powders - Part 3: Determination of density by liquid displacement pycnometer," International Organization for Standardization, Geneva, Switzerland.

ISO 8130-5 (1992). "Coating powders - Part 5: Determination of flow properties of a powder/air mixture," International Organization for Standardization, Geneva, Switzerland.

Jarusombuti, S., Ayrilmis, N., Bauchongkol, P., and Fueangvivat, V. (2010). "Surface characteristics and overlaying properties of MDF panels made from thermally modified rubberwood fibers," BioResources 5(2), 968-978. DOI: 10.15376/biores. 5.2.968-978.

Jirouš-Rajković, V., and Miklečić, J. (2019). "Heat-modified wood as a substrate for coatings, weathering of heat-modified wood, and coating performance on heatmodified wood," Advances in Materials Science and Engineering 2019, 1-9. DOI: 10.1155/2019/8621486.

Kymäläinen, M., Mlouka, S. B., Belt, T., Merk, V., Liljeström, R., Uimonen, T., Kostiainen, M., and Rautkari, L. (2018). "Chemical, water vapour sorption and ultrastructural analysis of Scots pine wood thermally modified in high-pressure reactor under saturated steam," Journal of Material Science 53, 3027-3037. DOI: 10.1007/s10853-017-1714-1.

Lee, S. S., Han, H. Z. Y, Hilborn, J. G., and Månson, J.-A. E. (1999). “Surface structure build-up in thermosetting powder coatings during curing," Progress in Organic Coatings 36(1-2), 79-88. DOI: 10.1016/S0300-9440(99)00029-6.

Miklečić, J., and Jirouš-Rajković, V. (2016). "Influence of thermal modification on surface properties and chemical composition of beech wood (Fagus sylvatica L.)," Drvna industrija 67(1), 65-71. DOI: 10.5552/drind.2016.1520.

Miklečić, J., Jirouš-Rajković, V., Antonović, A., and Španić, N. (2011). "Discolouration of thermally modified wood during simulated indoor sunlight exposure," BioResources 6(1), 434-446. DOI: 0.15376/biores.6.1.434-446.

Nejad, M., Dadbin, M., and Cooper, P. (2019). "Coating performance on exterior oil-heat modified wood," Coatings 9(4), 1-11. DOI: 10.3390/coatings9040225.

Petrič, M., Kutnar, A., Kričej, B., Pavlič, M., Kamke, F. A. and Šernek, M. (2009). "Surface free energy of viscoelastic thermal compressed wood," in: Contact Angle, Wettability and Adhesion, K. L. Mittal (ed.), Brill Academic Pub, Leide, Netherlands.

Petriccione, A. (2011). "Toward a new thermoplastic epoxy-based system: nanocomposite and fibre reinforced material by reactive processing," $\mathrm{Ph} . \mathrm{D}$. Dissertation, University of Naples Federico II, Napoli, Italy.

Prieto, J. and Kiene, J. (2018). Wood Coatings: Chemistry and Practice, Vincentz Network GmbH \& Co. KG, Hanover, Germany.

Schmidt, T., Jocham, C., Mayer, C., Blatter, A., Schwarz, T., Hauber, P., Lücke, D, Müller, U., and Kandelbauer, A. (2013). "Review - Influence of panel moisture content on powder coating of medium density fibreboard (MDF)," Pro Ligno 9(4), 


\section{5-21.}

Slabejová, G., Vidholdová, Z., and Šmidriaková, M. (2019). "Surface finishes for thermally modified beech wood," Acta Facultatis Xylologiae Zvolen 61(2), 41-50. DOI: 10.17423/afx.2019.61.2.04.

Zhang, Y., and Yu, W. (2015). "Changes in surface properties of heat modified Phyllostachys pubescens bamboo," BioResources 10(4), 6809-6818. DOI: 10.15376/biores.10.4.6809-6818.

Article submitted: July 20, 2021; Peer review completed: August 22, 2021; Revised version received: September 7, 2021; Accepted: September 14, 2021; Published: September 16, 2021.

DOI: $10.15376 /$ biores.16.4.7355-7366 